\title{
Abundance, biomass and size structure of the microbial assemblage in the high mountain lake Gossenköllesee (Tyrol, Austria) during the ice-free period
}

\author{
Anton WILLE*, Bettina SONNTAG, Birgit SATTLER and Roland PSENNER \\ Institute of Zoology and Limnology, Innsbruck University, Technikerstr. 25, A-6020 Innsbruck, Austria \\ *e-mail corresponding author: anton.wille@uibk.ac.at
}

\begin{abstract}
The abundance, biomass and morphology of the microbial components (picocyanobacteria, heterotrophic bacteria, heterotrophic and autotrophic nanoflagellates, ciliates) of the pelagic food web of Gossenköllesee were investigated over two summer periods. The density of bacteria remained relatively stable not only over time but also in vertical profiles $\left(2.5-5.5 \times 10^{5} \mathrm{cells}^{\mathrm{ml}} \mathrm{l}^{-1}\right)$. Bacterial biomass ranged between 35 to $63 \mathrm{mgC} \mathrm{m}^{-2}\left(5.4-15.3 \mu \mathrm{gCl} \mathrm{l}^{-1}\right)$. Small rod shaped bacteria with mean cell volumes of $\sim 0.05 \mu \mathrm{m}^{3}$ dominated numerically but filamentous forms (longer than $10 \mu \mathrm{m}$ ), mainly found in the upper water layers, amounting to more than $65 \%$ of the total bacterial biomass, increased the mean cell volume up to $0.27 \mu \mathrm{m}^{3}(S D=0.88)$. Bacterial biomass represented between 48 and $86 \%$ of the total microbial biomass $\left(40-90 \mathrm{mgC} \mathrm{m}^{-2}\right)$, however at $8 \mathrm{~m}$ depth the biomass of heterotrophic flagellates (HNF)

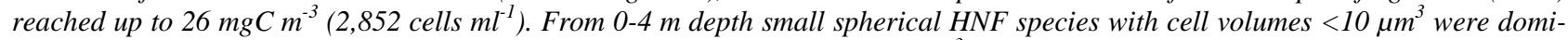
nant, whereas in deeper water layers large flagellates with cell volumes $>50 \mu^{3}$ dominated throughout the sampling period. Ciliate abundance was low in the upper part of the water column. Only Askenasia chlorelligera and Urotricha cf pelagica occurred with numbers of up to 1,500 cells $l^{-1}$. At $8 \mathrm{~m}$ depth, Balanion planctonicum was the dominant species throughout the study period reaching numbers of up to 16,000 cells $l^{-1}$. Ciliate abundance was significantly correlated with chlorophyll-a concentrations $\left(r_{s}=0.55, p\right.$ $<0.01)$ confirming the algivory of the dominant species. No significant correlation was found between the parameters of chlorophylla, bacteria and HNF but the abundance of ciliates was negatively correlated with the length of bacteria $\left(r_{s}=-0.41, p<0.05\right)$.
\end{abstract}

Key words: bacterioplankton, heterotrophic flagellates, ciliates, microbial biomass, alpine lake, high mountain lake

\section{INTRODUCTION}

High mountain lakes have been of interest to biologists since the beginning of this century (Zschokke 1900, Steinböck 1938, 1955). These lakes, situated above the timberline, have relatively small catchment areas with little or no vegetation and are, consequently very oligotrophic.

One of the first and basic information about living assemblages and biological processes of these ecosystems is given by Eppacher (1966), Pechlaner (1969) and Tilzer (1973). Compared to more eutrophic systems, the pelagic food webs of these oligotrophic lakes seem to be less complex (Fott et al. 1992) and the microbial loop might play an important role in recycling nutrients for higher trophic levels (Weisse \& Stockner 1993). Straškrabová \& Šimek (1993) suggested that the significance of the pelagic microbial assemblage increases with oligotrophication and acidification of the lake water.

Up to now little information is available on the temporal and spatial evolution of microbial pelagic food webs of high mountain lakes (e.g., Felip 1997), while many recent papers focus on more specific topics like the effect of UVB radiation on bacterivory (Sommaruga et al. 1996), bacterial diversity and activity (Alfreider et al. 1996; Posch et al. 1997; Pernthaler et al. 1998) and palaeolimnology (Koinig et al. 1998). Other authors describe the impact of the melting winter cover on microbial dynamics in the pelagic zone (Pernthaler et al. 1997; Andreatta 1998) or compare the microbial standing stock of various high mountain lakes (Sattler 1998).

This study was carried out within the Mountain Lakes Research (MOLAR) Program of the European Community (Patrick et al. 1998) to test the hypothesis that the importance of pelagic microbial food web increases with acidification. In this report we show the composition, biomass, size, and relationships between the members of the microbial food web (autotrophic picoplankton, heterotrophic bacteria, autotrophic / heterotrophic nanoflagellates, and ciliates) of Gossenköllesee throughout two ice-free summer seasons.

\section{MATERIAL AND METHODS}

\subsection{The study site}

Gossenköllesee, a small (1.7 ha) and shallow $\left(z_{\max }=9.9 \mathrm{~m}, \mathrm{z}_{\text {mean }}=4.7 \mathrm{~m}\right.$ ) lake is situated in a silicious catchment area in the Austrian Alps at the altitude of $2,417 \mathrm{~m}$ a.s.l. Further information about the most important chemical (Tab. 1) and hydrological parameters is given elsewhere (e.g., Felip et al. 1995; Sommaruga \& Psenner 1997; Thies et al. 1999).

\subsection{Sampling}

Samples were taken at the deepest point of the lake during the icefree period in summer 1996 and 1997. 
We took samples at 1, 2, 4, 6 and $8 \mathrm{~m}$ depth with a 5-L Schindler-Patalas sampler. Subsamples for all investigated organisms - bacterioplankton (BAC), heterotrophic nanoflagellates (HNF), autotrophic nanoflagellates (ANF; only in 1997), ciliates (CIL) and picocyanobacteria (PICY) - were collected from the same sampler.

\subsubsection{Enumeration, abundance and biomass}

Picocyanobacteria (PICY) - $100 \mathrm{ml}$ subsamples were fixed with NaCacodylate solution. $25 \mathrm{ml}$ were filtered onto black membrane filters and enumerated by epifluorescence microscopy using phycoerythrin excitation. A minimum of 200 counting grids were inspected.

\subsubsection{BAC, HNF and ANF}

Subsamples of $100 \mathrm{ml}$ were fixed with $36 \%$ formaldehyde (final conc. $2 \% \mathrm{v} / \mathrm{v}$ ) and stored at $4{ }^{\circ} \mathrm{C}$ until processing within 14 days. For enumeration, small volumes $(10-25 \mathrm{ml})$ were filtered onto black membrane filters (Poretics $0.2 \mu \mathrm{m}$ for BAC and $1 \mu \mathrm{m}$ for HNF/ANF, respectively), stained with the fluorochrome DAPI (4',6'-diamidino-2-phenylindole) and counted by epifluorescence microscopy (Zeiss Axioplan) according to Porter \& Feig (1980). A minimum of 400 bacteria were counted in at least 10 counting grids. We inspected a minimum of 200 counting grids for the estimation of flagellate numbers. Each flagellate was checked for autofluorescence by using green excitation.

Bacterial cell volumes and shapes were determined with an image analysis system (LUCIA, Laboratory Imaging, Prague, CZ) as described by LofererKrößbacher et al. (1998). Cell volumes (V) were converted to bacterial biomass $(C)$ using the equation given by Norland (1993)

$$
C(\mathrm{fg})=120 \times V^{0.76}
$$

For estimating HNF and ANF biomass, cell lenghts $(L)$ and widths $(w)$ of 50 individuals were measured. We considered flagellates as prolate spheroids and calculated therefore the cell volumes as

$$
V=(\pi / 6 \times L) \times w^{2}
$$

Cell volumes were converted to carbon units using the factor of $220 \mathrm{fg} \mathrm{C}$ per $\mu \mathrm{m}^{3}$ biovolume (Borsheim \& Bratback 1987).

For ciliates, subsamples of $500 \mathrm{ml}$ lake water were fixed with acid Lugol's solution. In case of longer storage they were postfixed with $50 \mathrm{ml}$ of filtered formaldehyde $36 \%$. Ciliates were counted under an inverse microscope (Zeiss Axiovert) after sedimentation of a $60 \mathrm{ml}$ subsample into Utermöhl chambers $(500 \mathrm{ml}$ when CIL were very scarce). The size of at least 30-50 ciliates was determined by using an eyepiece micrometer. Biovolumes were corrected by a shrinking factor of 1.4 ( Müller \& Geller 1993) and converted to carbon units using the factor of $140 \mathrm{fgC}$ per $\mu \mathrm{m}^{3}$ biovolume (Putt \& Stoecker 1989). For a more detailed description of sampling and elaboration procedures see Straškrabová et al. (1999, this issue).

Physical and chemical background data were collected by applying the methods described in the methodical manual of the MOLAR project (Wathne 1996) and by Thies et al. (1999).

\section{RESULTS}

\subsection{Temperature, chlorophyll-a and nutrients in 1997}

Spring thermal mixis began already during the melting phase of the lake ice-cover by the end of June. One week after ice break-up (July $3^{\text {rd }}$ ) the lake was completely stratified. The epilimnion expanded down to $4 \mathrm{~m}$ depth with temperatures between 11 and $13.1^{\circ} \mathrm{C}$ (August - September). At $8 \mathrm{~m}$ depth, the temperatures remained relatively low $\left(6-8{ }^{\circ} \mathrm{C}\right)$ throughout the summer season (Fig. 1a). With ongoing stratification the chlorophyll- $a$ maximum shifted down to the deepest layer and remained there until autumnal mixis (Tab. 1). Except in September the whole water column was well oxygenated (oxygen saturation: 97-105\%). Maximum values were observed in August at 6 and $8 \mathrm{~m}$ depth with up to $125 \%$ saturation (Fig 1b). Total dissolved phosphorous (TDP) (Fig. 1d) accounted for 15 to $70 \%$ of total phosphorous and reached the maximum value of $1.8 \mathrm{\mu g} \mathrm{l}^{-1}$ at $8 \mathrm{~m}$ depth in July and September. Dissolved organic carbon (DOC) was between 0.31 and $0.54 \mathrm{mg} \mathrm{l}^{-1}$ and tended to increase during summer (Fig 1c), it was highest at the surface during the autumnal mixis in October (Tab. 1).

Tab. 1. Range of the main chemical parameters during the 1997 sampling period.

\begin{tabular}{lcccc}
\hline & & mean & $\min$ & $\max$ \\
Temperature & $\left({ }^{\circ} \mathrm{C}\right)$ & 8.4 & 4.6 & 13.1 \\
$\mathrm{pH}$ & & 7.0 & 6.7 & 7.2 \\
Conductivity $25^{\circ} \mathrm{C}$ & $\left(\mu \mathrm{S} \mathrm{cm}^{-1}\right)$ & 20.7 & 19.6 & 23.9 \\
Alkalinity & $\left(\mu \mathrm{eq} \mathrm{l}^{-1}\right)$ & 96.6 & 89.0 & 112.0 \\
$\mathrm{O}_{2}$ & $\left(\mathrm{mg} \mathrm{l}^{-1}\right)$ & 9.0 & 7.6 & 11.1 \\
Total Phosphorous & $\left(\mu \mathrm{g} \mathrm{l}^{-1}\right)$ & 2.7 & 1.5 & 6.2 \\
Tot. Dissolved Phosph. & $\left(\mu \mathrm{g} \mathrm{l}^{-1}\right)$ & 1.0 & 0.6 & 1.8 \\
DOC & $\left(\mathrm{mg} \mathrm{l}^{-1}\right)$ & 0.4 & 0.3 & 0.5 \\
Dissolved Nitrogen & $\left(\mathrm{mg} \mathrm{l}^{-1}\right)$ & 0.3 & 0.3 & 0.4 \\
Chlorophyll- $a$ & $\left(\mu \mathrm{g} \mathrm{l}^{-1}\right)$ & 1.8 & 0.7 & 3.7 \\
\hline
\end{tabular}

\subsection{Abundances}

Picocyanobacteria occurred at very small densities ranging from 0 to 696 cells $\mathrm{ml}^{-1}$ throughout the two sampling periods. Therefore, no cell-volumes were estimated. Most cells were attached to detritus aggregates and no specific pattern of distribution could be observed (data not shown).

Bacterial cell numbers ranged between 2.5 and $5.5 \times 10^{5} \mathrm{ml}^{-1}$ (Tab. 2). In both summer seasons the bacterial abundance slightly increased towards autumn. 


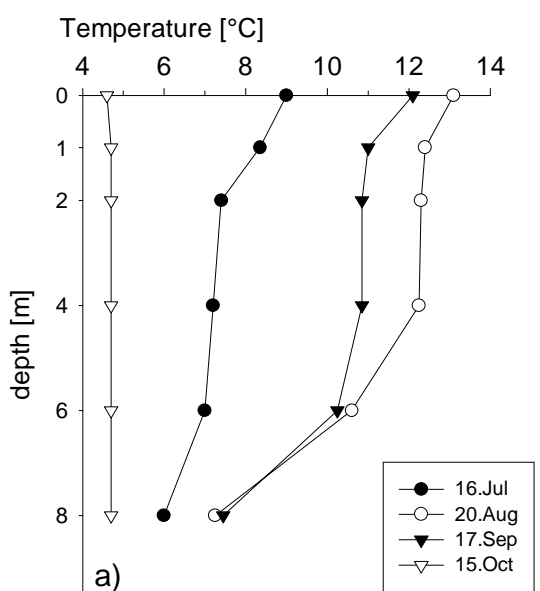

Oxygen $\left[\mathrm{mg} \mathrm{l}^{-1}\right]$
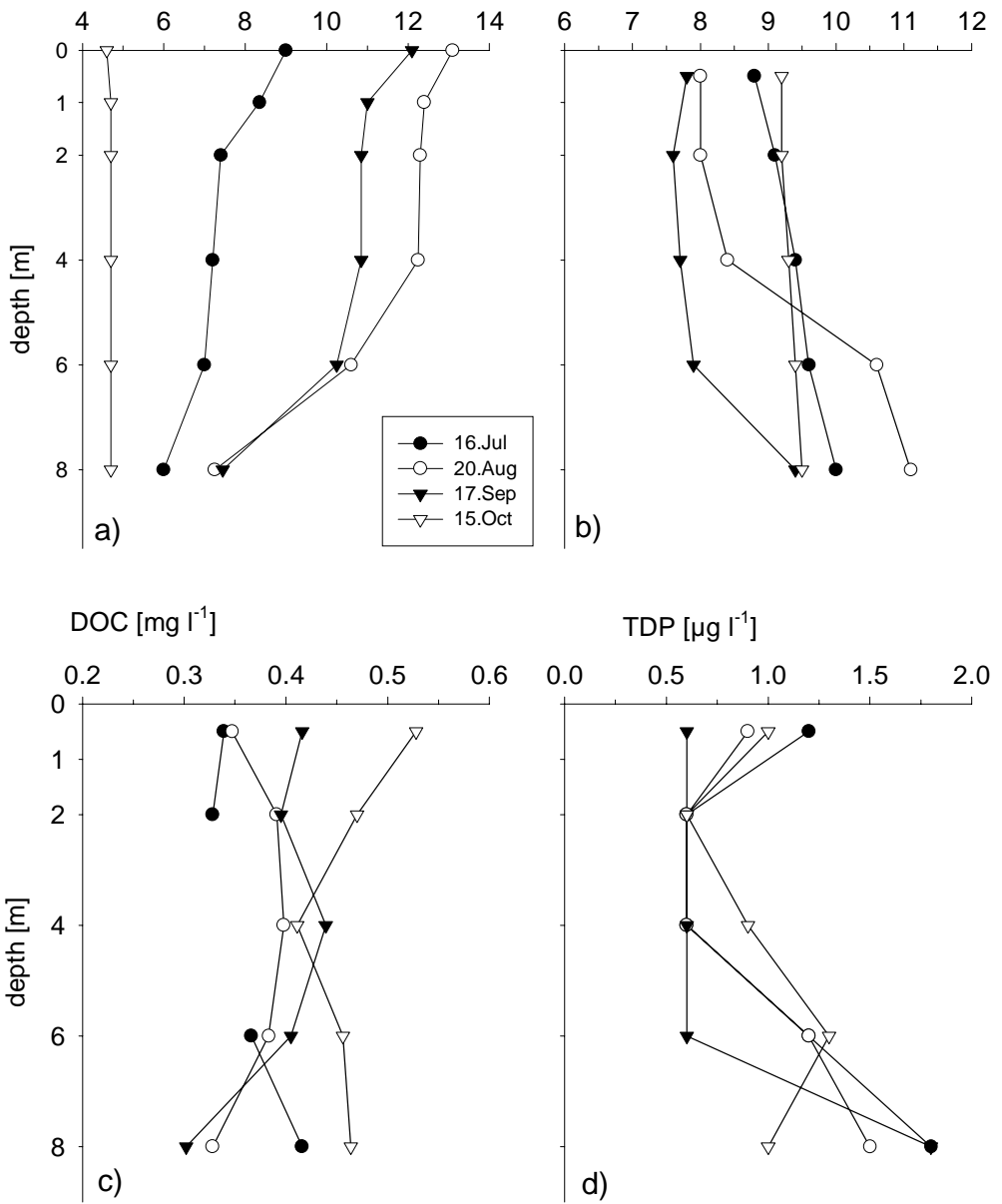

$\operatorname{TDP}\left[\mu \mathrm{g}^{-1}\right]$

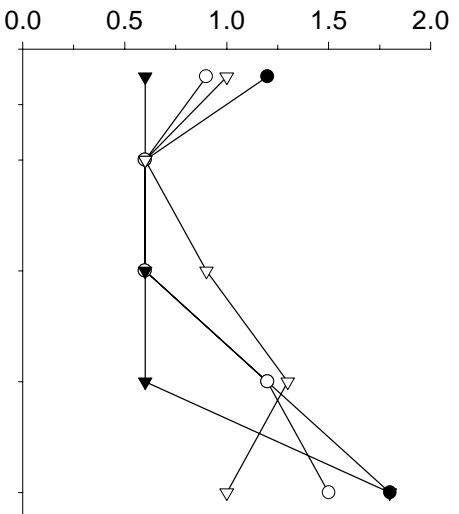

Fig. 1. Vertical profile of a) Temperature $\left.\left(\mathrm{T}^{\circ} \mathrm{C}\right), \mathrm{b}\right)$ dissolved oxygen $\left(\mathrm{O}_{2}\right)$, c) dissolved organic carbon (DOC), and d) total dissolved phosphorous (TDP) during the ice-free period 1997.

Tab. 2. Mean abundance of the microbial components (minimum and maximum values are in brackets). Mean values are weighted over the water column; $n=5$, except for ciliates $(n=3)$. n.d. not determined.

\begin{tabular}{|c|c|c|c|c|c|}
\hline Date & $\begin{array}{c}\text { ANF } \\
\left(\text { cells ml }{ }^{-1} \text { ) }\right.\end{array}$ & $\begin{array}{c}\text { PICY } \\
\left(\text { cells ml }{ }^{-1}\right)\end{array}$ & $\begin{array}{c}\mathrm{HNF} \\
\left(\text { cells } \mathrm{ml}^{-1} \text { ) }\right.\end{array}$ & $\begin{array}{c}\text { BAC } \\
\left(\text { cells } \times 10^{5} \mathrm{ml}^{-1}\right)\end{array}$ & $\begin{array}{c}\mathrm{CIL} \\
\left(\text { cells ml }{ }^{-1}\right)\end{array}$ \\
\hline 23. Jul 1996 & n.d. & $\begin{array}{c}318 \\
(267-493)\end{array}$ & $\begin{array}{c}1156 \\
(598-2260)\end{array}$ & $\begin{array}{c}3.77 \\
(3.28-4.19)\end{array}$ & $\begin{array}{c}2672 \\
(333-16483)\end{array}$ \\
\hline 06. Aug 1996 & n.d. & $\begin{array}{c}491 \\
(477-696)\end{array}$ & $\begin{array}{c}920 \\
(567-2852)\end{array}$ & $\begin{array}{c}3.21 \\
(2.96-3.26)\end{array}$ & $\begin{array}{c}2458 \\
(716-13383)\end{array}$ \\
\hline 16. Aug 1996 & n.d. & $\begin{array}{c}385 \\
(145-473)\end{array}$ & $\begin{array}{c}739 \\
(610-1108)\end{array}$ & $\begin{array}{c}3.55 \\
(2.53-3.83)\end{array}$ & $\begin{array}{c}2969 \\
(616-16666)\end{array}$ \\
\hline 03. Sep 1996 & n.d. & $\begin{array}{c}247 \\
(236-267)\end{array}$ & $\begin{array}{c}562 \\
(418-1050)\end{array}$ & $\begin{array}{c}4.48 \\
(3.36-4.96)\end{array}$ & $\begin{array}{c}282 \\
(233-516)\end{array}$ \\
\hline 17. Jul 1997 & $\begin{array}{c}634 \\
(482-1123)\end{array}$ & $\begin{array}{c}99 \\
(0-205)\end{array}$ & $\begin{array}{c}335 \\
(321-431)\end{array}$ & $\begin{array}{c}2.82 \\
(2.80-3.16)\end{array}$ & $\begin{array}{c}2054 \\
(112-12771)\end{array}$ \\
\hline 21. Aug 1997 & $\begin{array}{c}867 \\
(624-3363)\end{array}$ & $\begin{array}{c}252 \\
(0-357)\end{array}$ & $\begin{array}{c}681 \\
(482-2299)\end{array}$ & $\begin{array}{c}3.83 \\
(3.44-5.45)\end{array}$ & $\begin{array}{c}1179 \\
(861-2078)\end{array}$ \\
\hline 17. Sep 1997 & $\begin{array}{c}1343 \\
(1040-2100)\end{array}$ & $\begin{array}{c}136 \\
(124-171)\end{array}$ & $\begin{array}{c}474 \\
(283-808)\end{array}$ & $\begin{array}{c}3.37 \\
(2.90-5.25)\end{array}$ & $\begin{array}{c}1091 \\
(250-6116)\end{array}$ \\
\hline 15. Oct 1997 & $\begin{array}{c}634 \\
(406-917)\end{array}$ & $\begin{array}{c}269 \\
(141-393)\end{array}$ & $\begin{array}{c}343 \\
(227-539)\end{array}$ & $\begin{array}{c}4.82 \\
(4.41-5.35)\end{array}$ & $\begin{array}{c}3270 \\
(2888-3700)\end{array}$ \\
\hline
\end{tabular}

The vertical distribution of bacterial abundance was rather homogeneous in 1996 when lowest values were always found at $8 \mathrm{~m}$ and the difference to the other depths never exceeded 52\%. Contrastingly, in 1997 the 6 and $8 \mathrm{~m}$ water-layers showed highest abundances and differed from the other depths by up to $125 \%$ (Fig. 2).
With the exception of $8 \mathrm{~m}$ depth, HNF abundance in $1996\left(5.6 \times 10^{2}\right.$ to $1.5 \times 10^{3}$ cells $\left.\mathrm{ml}^{-1}\right)$ was about twice as high as in 1997 ( 2.3 to $8.1 \times 10^{2}$ cells $\mathrm{ml}^{-1}$ ) (Tab. 2). Highest cell numbers of up to $2.85 \times 10^{3}$ cells ml ${ }^{-1}$ were found between July and August at $8 \mathrm{~m}$ depth near the lake bottom in both years (Fig. 2). The abundance of 


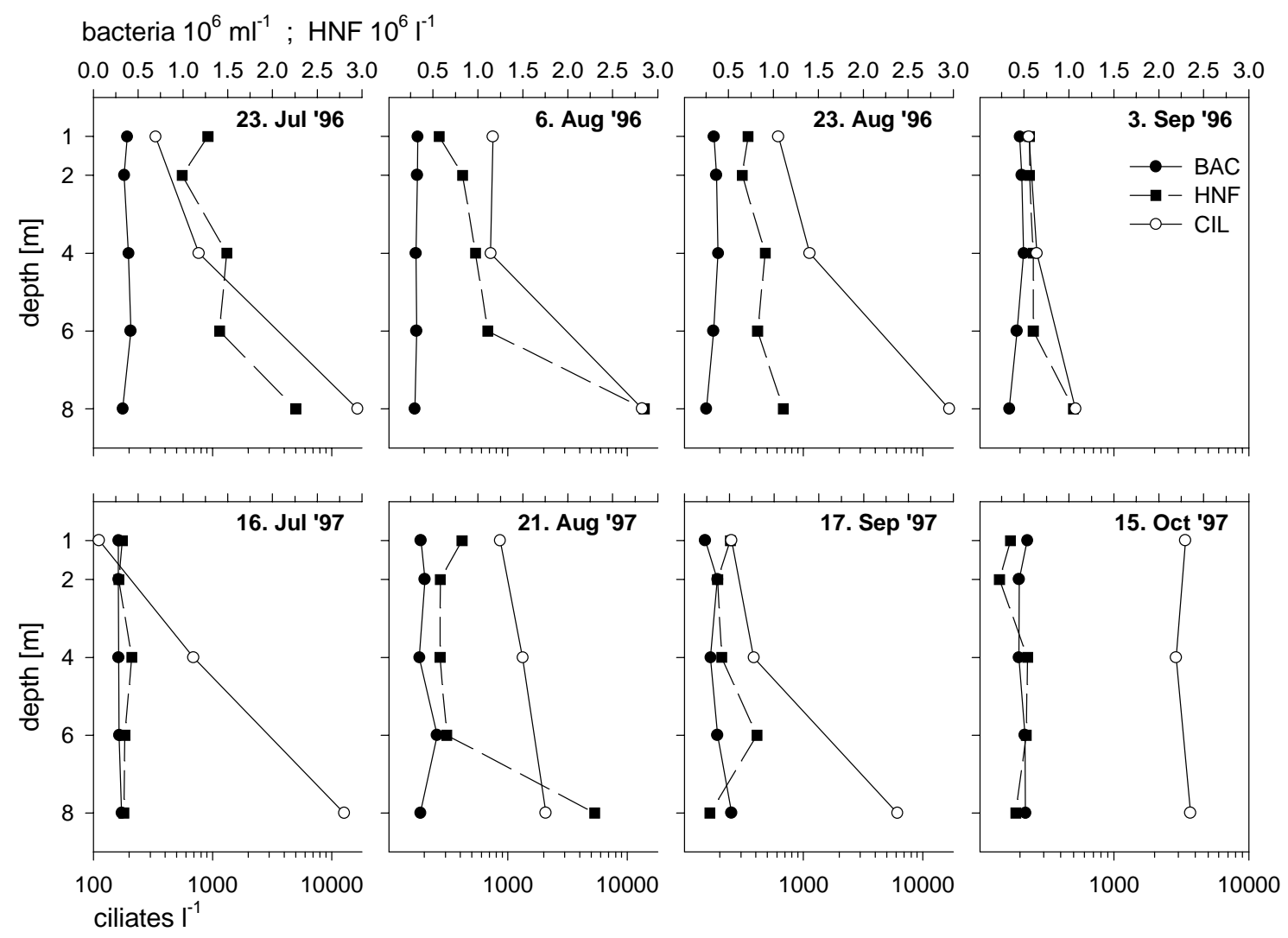

Fig. 2. Temporal and vertical distribution of the abundance of heterotrophic microorganisms during the ice-free season 1996 and 1997. HNF - heterotrophic nanoflagellates.

ANF, counted only in 1997 , ranged between $4.83 \times 10^{2}$ and $3.36 \times 10^{3}$ cells $\mathrm{ml}^{-1}$ and showed the highest values at $8 \mathrm{~m}$ depth.

During both ice-free periods only three abundant ciliate species could be observed (Fig. 3). The cyclotrich ciliate Askenasia chlorelligera was present in all samples with numbers between 40 and 1,500 cells $1^{-1}$. Urotricha cf pelagica occurred only at low abundances (17-133 cells $\left.1^{-1}\right)$. Another prostomatide ciliate, Balanion planctonicum, found at 6 and $8 \mathrm{~m}$ depth only, reached high densities of up to 16,300 ind $1^{-1}$. Halteria grandinella appeared only once with 17 cells $1^{-1}$. Additionally some single observations of Lagynophrya accuminata and Paramecium cf putrinum completed the species list of the ciliate assemblage.

\subsection{Morphological diversity of bacterioplankton and heterotrophic nanoflagellates}

Comparing the epilimnetic (1-4 m depth) and metahypolimnetic (6-8 m depth) layers, we could distinguish different morphotypes of the microbial assemblage during summer stratification. In both years a very similar pattern was observed (shown for 1996 in Fig. 4): bacterioplankton was always dominated by small rod-shaped forms with a cell volume of $0.05 \mu \mathrm{m}^{3}$. Towards autumn the frequency of filamentous forms (longer than $50 \mu \mathrm{m}$ ) increased in the upper water-lay- ers, whereas in $8 \mathrm{~m}$ depth the abundance of threadlike bacteria remained small until fall overturn. Therefore, higher mean cell volumes were found at the surface (total range from 0.076 up to $0.265 \mu \mathrm{m}^{3}$ ) than in deeper water-layers (total range $0.076-0.144 \mu \mathrm{m}^{3}$ ).

Small HNF-species of up to $5 \mu \mathrm{m}$ cell length, corresponding to a cell volume of $3-35 \mu \mathrm{m}^{3}$, were dominant at the surface-layers but were less frequent near the bottom. Larger, 7 to $10 \mu \mathrm{m}$ long flagellates with cell volumes $>50 \mu \mathrm{m}^{3}$ occurred mainly at $8 \mathrm{~m}$ depth where they accounted for up to $85 \%$ of the total abundance (Fig. 4).

\subsection{Biomass}

Integrated microbial biomass ranged between 40 and $94 \mathrm{mgC} \mathrm{m}^{-2}\left(8.5-20 \mu \mathrm{gC} \mathrm{l}^{-1}\right)$ showing a trend to increase towards the autumn. Except for one date, bacterial biomass accounted $>50 \%(43-81 \%)$ of total heterotrophic microbial biomass, whereas HNF and CIL contributed 9 to $44 \%$ and 4 to $21 \%$, respectively (Fig. $5)$.

The spatial range of heterotrophic biomass is listed in table 3. During thermal stratification maximum values of up to $39 \mu \mathrm{gC} \mathrm{l}^{-1}$ occurred at $8 \mathrm{~m}$ depth. Only there the proportion of the protists exceeded bacterial standing stock (Fig. 6). 

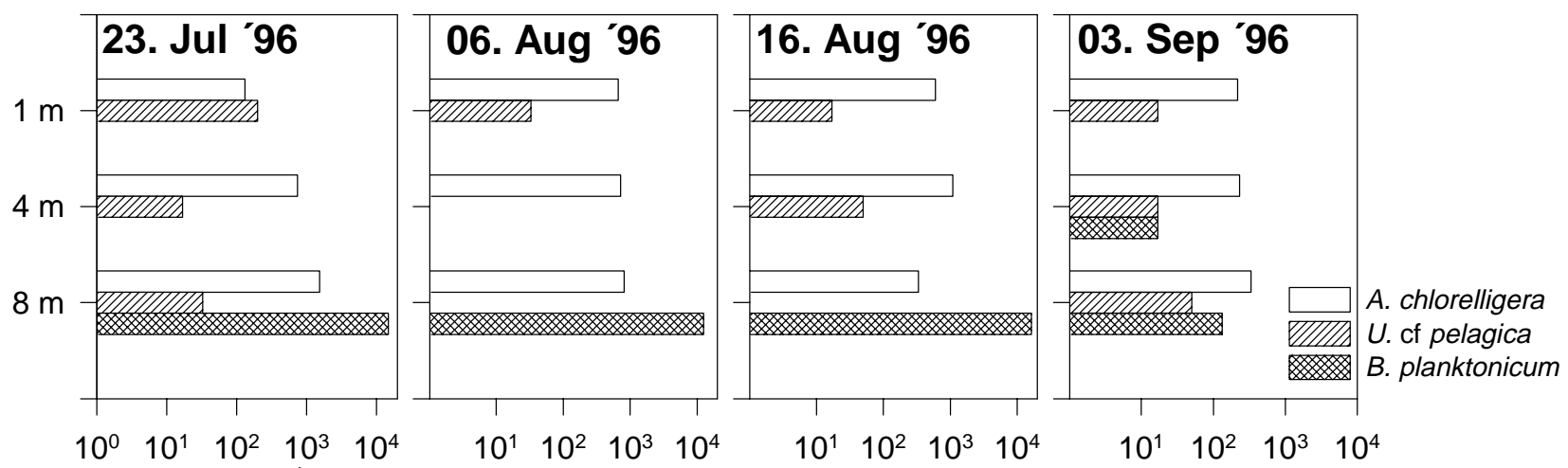

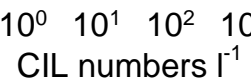
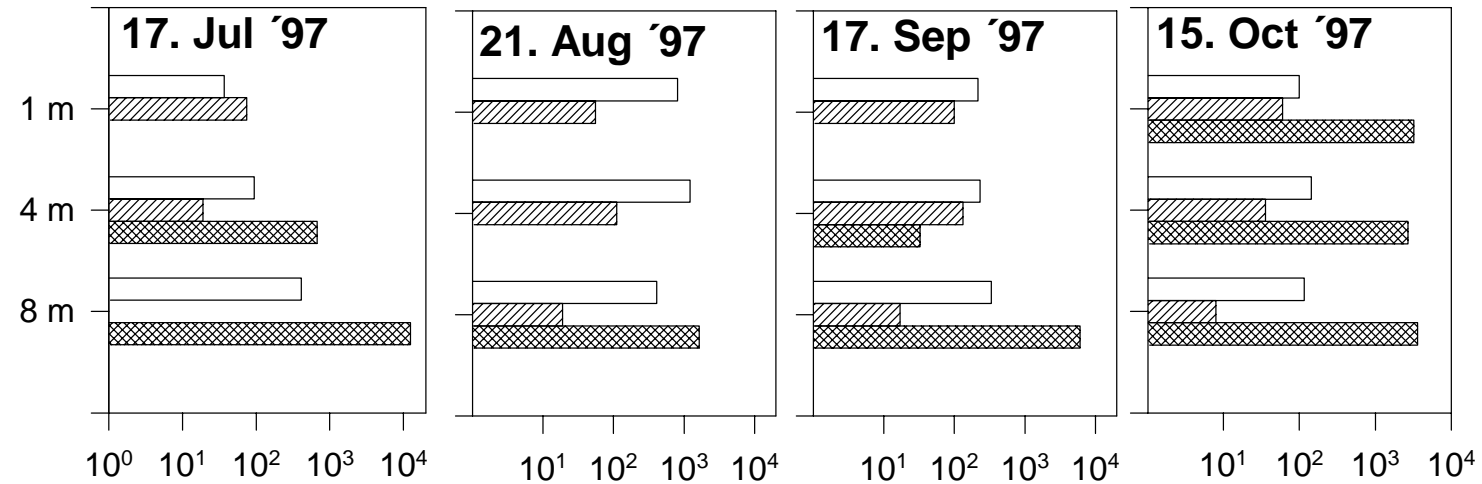

Fig. 3. Temporal and spatial distribution of abundant ciliate species during the ice-free period 1996 and 1997.

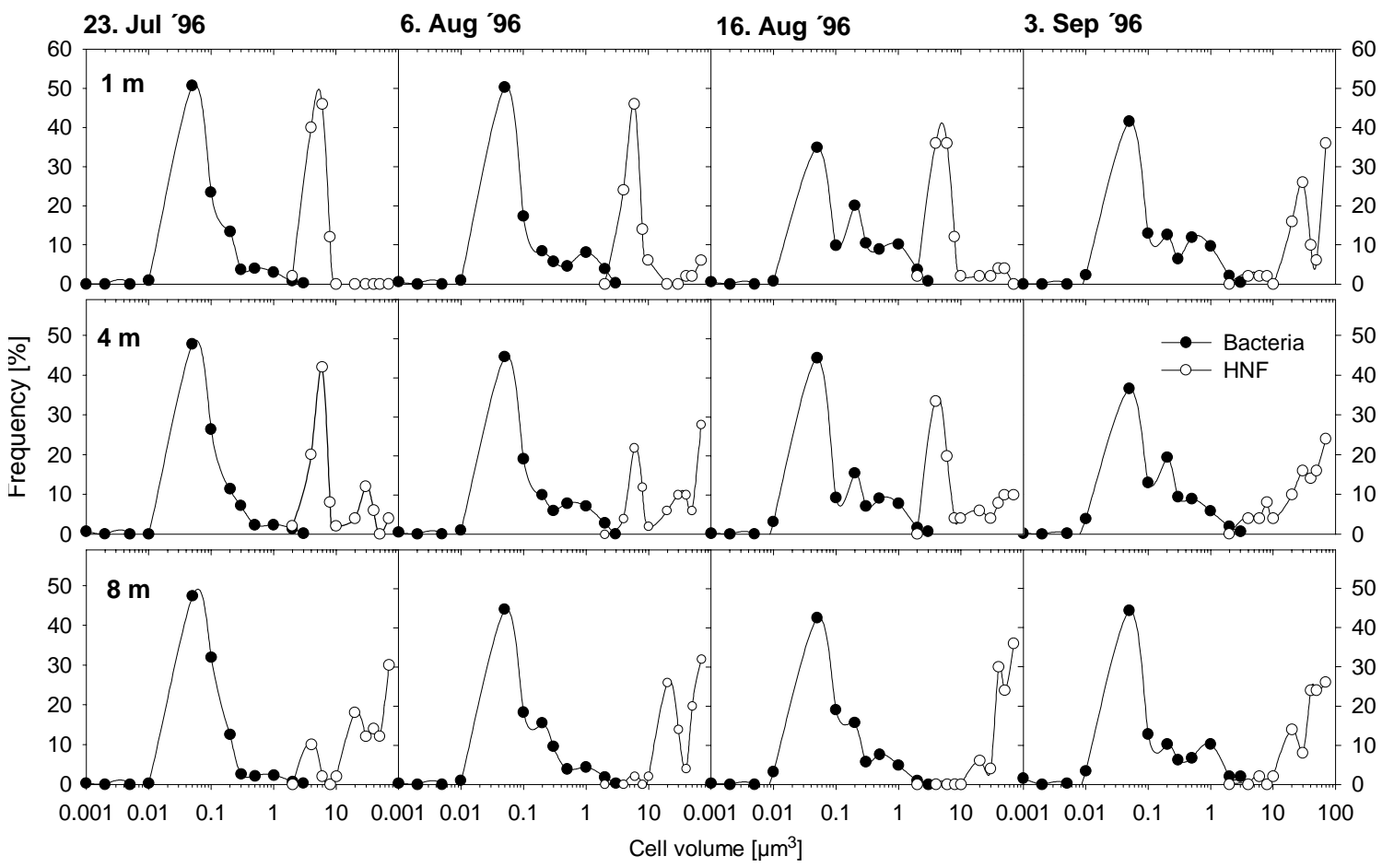

Fig. 4. Cell volume distribution of bacteria and heterotrophic nanoflagellates during summer 1996. 
Bacterial biomass ranged between 5.4 and $15.3 \mu \mathrm{gC}$ $\mathrm{I}^{-1}$ and was significantly influenced by the length of the cells $\left(r_{\mathrm{s}}=0.68, \mathrm{p}<0.001 ;\right.$ Tab. 4). Filaments longer than $6.4 \mu \mathrm{m}$ formed 16 to $67 \%$ of the bacterial standing stock (Fig. 7). This means that a considerable amount of bacterial biomass cannot be ingested by flagellates and smaller ciliates. The mean carbon content of a single bacterial cell was between 16.4-37.1 fg with lowest values occurring at $8 \mathrm{~m}$ depth.
The biomass of HNF ranged between 0.5 and 13.6 $\mu \mathrm{gC} \mathrm{l}^{-1}$ from 1-6 $\mathrm{m}$ depth, highest values were observed in both years in August at $8 \mathrm{~m}$ depth with 26.1 and $25.3 \mu \mathrm{gC} 1^{-1}$, respectively. At this time also ANF, with the dominant genus Rhodomonas sp., showed a biomass peak of $67 \mu \mathrm{gC} \mathrm{I}^{-1}$ at $8 \mathrm{~m}$, whereas in other depths the biomass was equivalent to the bacterial standing stock (Tab. 3).

The biomass of Askenasia chlorelligera $\left(\mathrm{L}_{\text {mean }}=\right.$

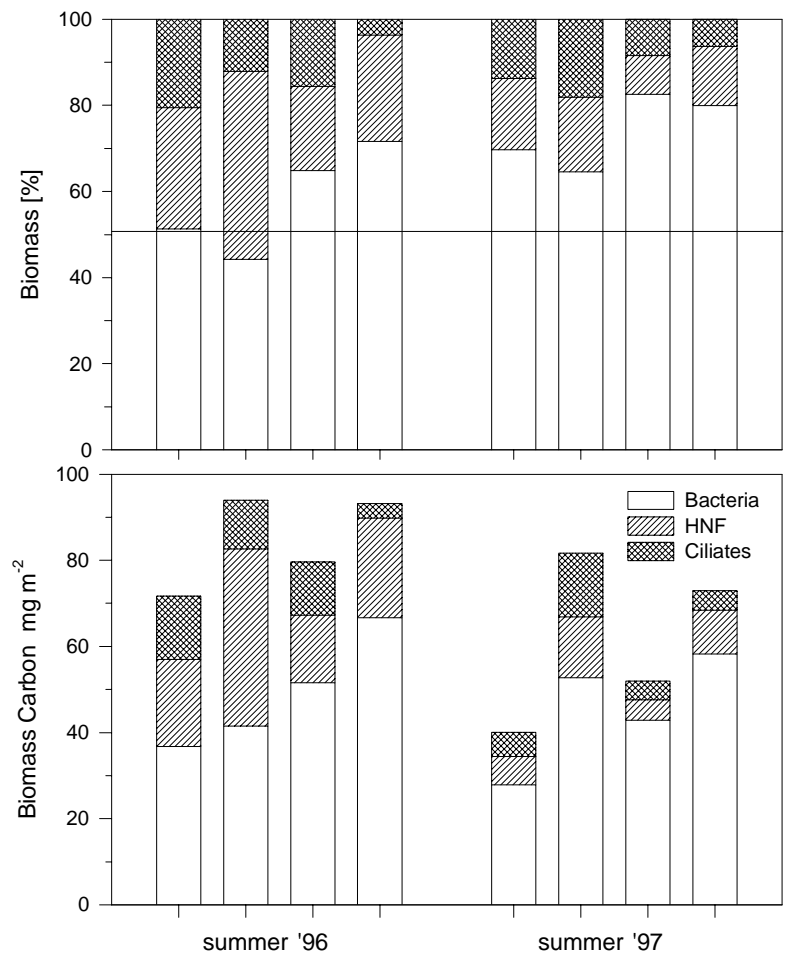

Fig. 5. Total microbial biomass of bacteria, heterotrophic nanoflagellates and ciliates in the water column during summer 1996 and 1997(weighted means).

Tab. 3. Mean biomass $\left(\mathrm{mgC} \mathrm{m} \mathrm{m}^{-3}\right)$ of the microbial components (minimum and maximum values are in brackets). Mean values are weighted over the water column; $\mathrm{n}$ $=5$, except for ciliates $(\mathrm{n}=3)$. n.d. not determined.

\begin{tabular}{lcccc}
\hline Date & ANF & HNF & BAC & CIL \\
\hline 23. Jul 1996 & n.d. & 3.39 & 8.58 & 3.22 \\
06. Aug 1996 & n.d. & $(1.3-18.0)$ & $(6.5-10.9)$ & $(1.2-10.8)$ \\
& & $(1.9-26.1)$ & $(7.6-9.6)$ & $(2.0-5.1)$ \\
16. Aug 1996 & n.d. & 2.81 & 11.29 & 2.72 \\
& & $(1.2-11.4)$ & $(6.1-12.5)$ & $(1.8-5.1)$ \\
03. Sep 1996 & n.d. & 4.62 & 14.58 & 0.75 \\
& & $(4.0-9.1)$ & $(11.6-15.3)$ & $(0.7-1.1)$ \\
17. Jul 1997 & 8.11 & 1.43 & 6.11 & 1.21 \\
& $(6.4-14.0)$ & $(0.6-3.4)$ & $(5.4-7.6)$ & $(0.5-5.6)$ \\
21. Aug 1997 & 6.31 & 3.10 & 11.52 & 3.24 \\
& $(2.5-67.0)$ & $(1.3-25.3)$ & $(7.1-12.8)$ & $(1.7-4.8)$ \\
17. Sep 1997 & 7.21 & 1.02 & 9.39 & 0.96 \\
& $(2.3-23.9)$ & $(0.5-4.4)$ & $(7.4-12.1)$ & $(0.9-1.2)$ \\
15. Oct 1997 & 11.85 & 2.21 & 12.75 & 0.99 \\
& $(7.1-20.9)$ & $(1.5-3.2)$ & $(11.1-14.5)$ & $(0.9-1.0)$ \\
\hline
\end{tabular}




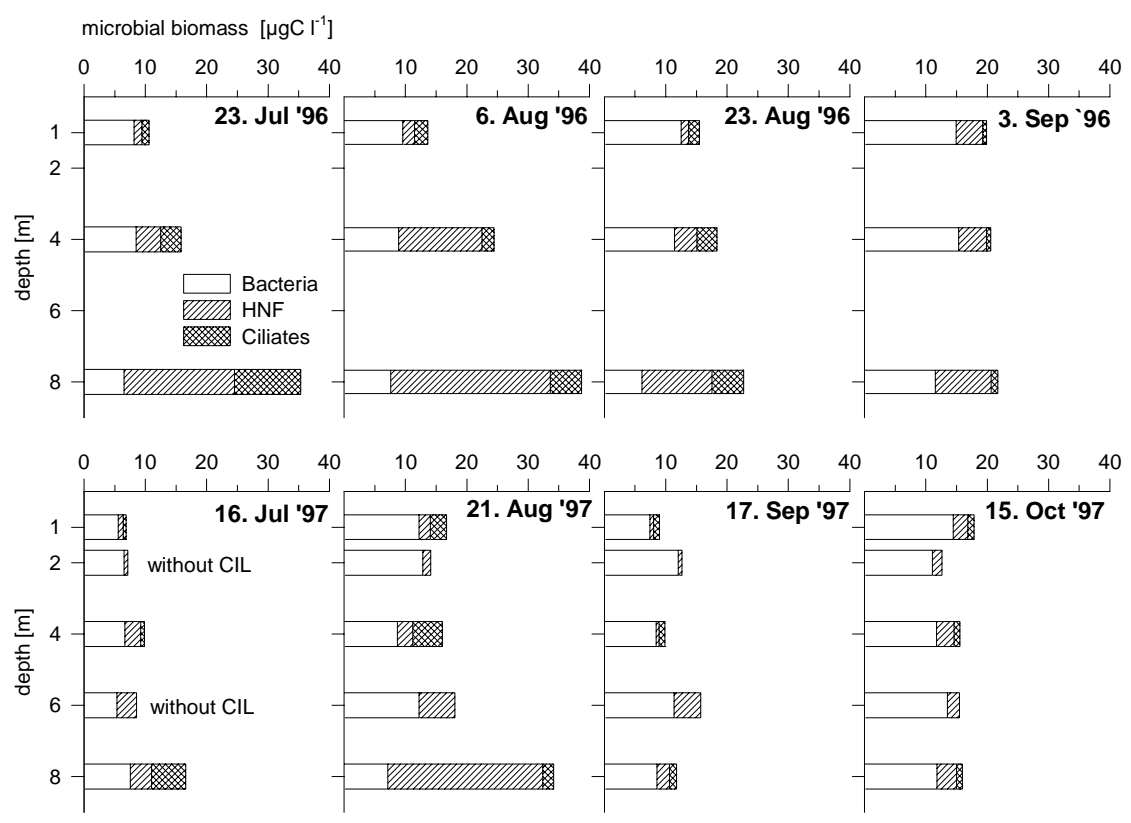

Fig. 6. Spatial distribution of heterotrophic microbial biomass. Note that 2 and $6 \mathrm{~m}$ in 1997 are without ciliate biomass. HNF heterotrophic nanoflagellates; CIL - ciliates

Tab. 4. Spearman Rank correlation matrix for microbial parameters for the ice-free periods of 1996 and 1997; $n=32$, except for ciliates $(n=24)$; level of significance: * $\mathrm{p}<0.05 ; * * \mathrm{p}<0.01 ; * * * \mathrm{p}<0.001$. CIL - ciliate abundance; BAC - bacterial abundance; HNF - heterotrophic nanoflagellates; BL - mean bacterial cell length; BB - mean bacterial biomass; chl $a$ - chlorophyll $a$.

\begin{tabular}{lcrlrc}
\hline & CIL & HNF & \multicolumn{1}{c}{ BL } & BB & BAC \\
\hline Chl- $a$ & $0.55^{* *}$ & 0.02 & 0.02 & -0.14 & 0.05 \\
BAC & 0.10 & -0.06 & 0.29 & $0.76^{* * *}$ & \\
BB & -0.22 & 0 & $0.68 * * *$ & & \\
BL & $-0.41^{*}$ & -0.27 & & & \\
HNF & 0.14 & & & & \\
\hline
\end{tabular}

31.1, $\left.\mathrm{w}_{\text {mean }}=31.3 \mu \mathrm{m}\right)$ ranged between 0.1 and $6.8 \mu \mathrm{gC}$ $1^{-1}$ and represented $2-49 \%$ of the ciliate biomass. Because of its abundances the small Balanion planctonicum $\left(\mathrm{L}_{\text {mean }}=14.6, \mathrm{w}_{\text {mean }}=11.9 \mu \mathrm{m}\right)$ contributed 0.2-4.3 $\mu \mathrm{gC}^{-1}$ (up to $51 \%$ ) to the biomass of the pelagic ciliates.

\section{DISCUSSION}

Compared to various marine and freshwater systems, the observed bacterial abundance of $3.73 \times 10^{5}$ cells $\mathrm{ml}^{-1}$ is at the lower end of the range (Riemann \& Christoffersen 1993), but it seems to be typical for high alpine lakes (Sattler 1998). Certainly, total bacterial numbers are useful to describe existing carbon pools in systems but in fact it is not the only variable when discussing food availability for higher trophic levels (Sherr et al. 1992). In this case other parameters such as the physiological activity or the shape and size of the bacterial cells are important (Gonzales et al. 1990; Gasol et al. 1995). Thus the abundance of the available prey will be reduced by a remarkable amount when we consider that the largest flagellate in Gossenköllesee (length $=7-8 \mu \mathrm{m}$ ), may ingest only small bacteria of 2$3 \mu \mathrm{m}$ length (see Figs 4, 7).

The occurrence of filamentous bacteria (length $>10 \mu \mathrm{m})$ in Gossenköllesee is already known from various studies (Posch et al. 1997; Pernthaler et al. 1998). During and shortly after ice-break only small rod shaped cells occur in the water column (Pernthaler et al. 1997) but filamentous forms, members of the Cytophaga-Flavobacterium group (Pernthaler et al. 1998), develop during summer in the upper part of the water column and account for more than $50 \%$ of the total bacterial biomass.

Oligotrophic high mountain lakes generally show low abundances of heterotrophic nanoflagellates and sometimes they are under the detection limit (Sattler 1998). With the exception of the distinct peaks in August, the densities in Gossenköllesee are comparable to other alpine lakes of the Tyrol and Carinthia (0- 
$1.57 \times 10^{3} \mathrm{ml}^{-1}$ ) (Sattler 1998). As the abundance of the bacterioplankton is below the assumed threshold density for supporting the nutrition of heterotrophic nanoflagellates (Riemann et al. 1995), they might survive by mixo- or osmotrophy (Sanders 1991). Due to low particle density, low content of dissolved nutrients, and ambient light conditions even at the lake bottom, the nutrition often is based on mixotrophy (Stockner \& Porter 1987; Havskum \& Riemann 1996). This nutrition strategy could explain the large discrepancy between the biomasses of heterotrophic nanoflagellates and their prey bacteria, specially at $8 \mathrm{~m}$ depth (Fig. 6). terial abundance and biomass because flagellates can graze effectively on newly produced bacterial cells. Riemann et al. (1995) showed that mixotrophic flagellates are able to switch between phago- and autotrophy within several hours by changing the chl- $a$ content depending on the particle density of the prey. Specially at $8 \mathrm{~m}$ depth we often had problems to distinguish between auto- or heterotrophy of the dominant flagellate species because they did not show a distinct chloroplast, and the autofluorescence was very weak.

Following to the chl- $a$ maxima Balanion planctonicum peaked at the bottom layer of the lake. This prostomatide ciliate is known to be an effective grazer on
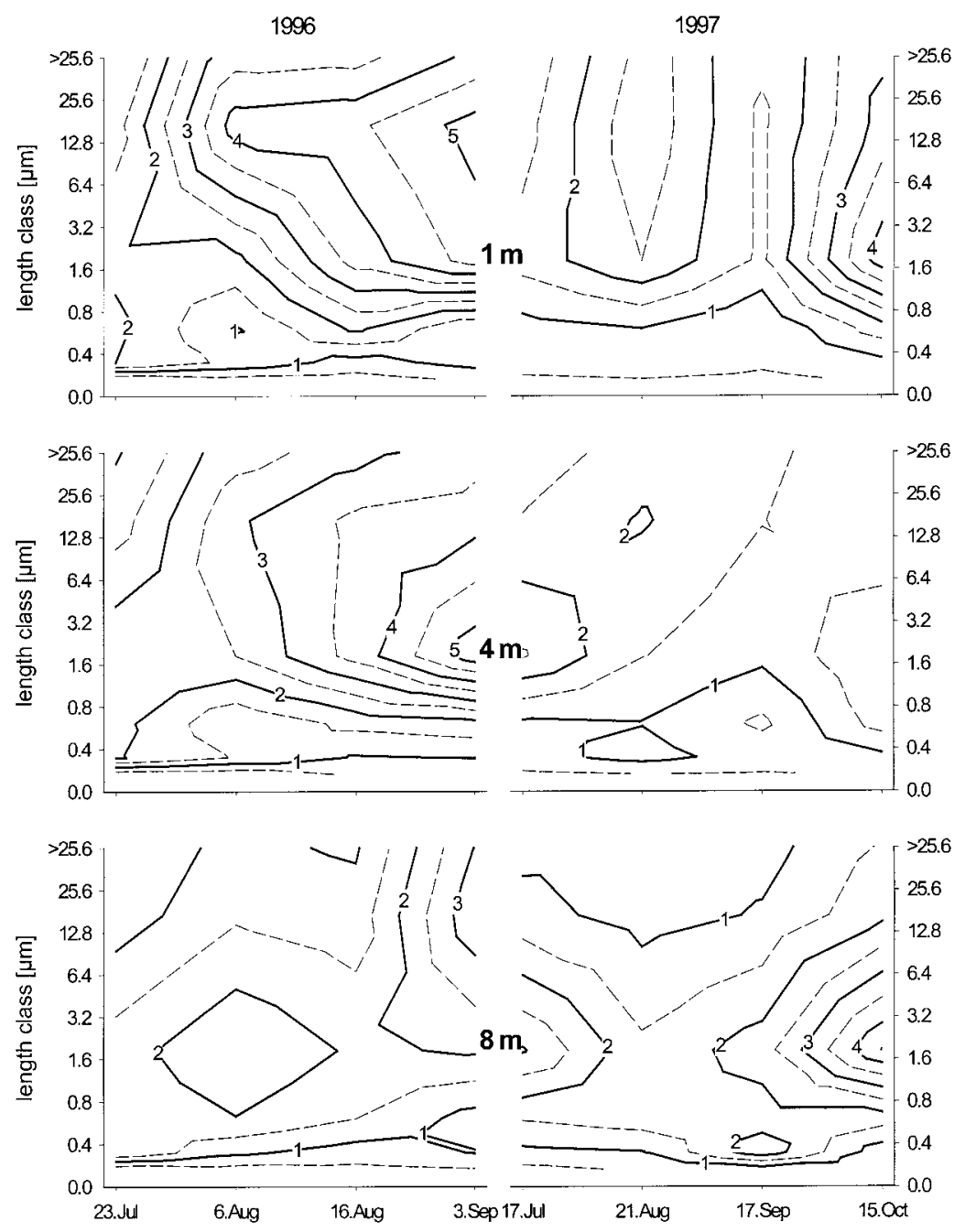

Fig. 7. Size dependant distribution of the bacterial biomass. Units are given in $\mu \mathrm{g} \mathrm{Cl}^{-1}$.

Sanders et al. (1990) stated that the change from photo- to phagotrophy can occur simultaneously with increasing particle density. According to Stockner \& Porter (1987), and del Giorgio et al. (1996) this fact could explain the small seasonal variability of the bac- the phytoflagellate Rhodomonas sp. (e.g., Kentner et al. 1996), which was the dominant algal species in $8 \mathrm{~m}$ depth. Sommaruga \& Psenner (1995), who studied the development of $B$. planctonicum in a subalpine lake, suggested that it may react much faster on increasing 
densities of Rhodomonas sp. than metazooplankton, thus inducing the clear water phase in lakes which are later dominated by cladocerans. While B. planktonicum was restricted to layers including Rhodomonas, the other species, Askenasia chlorelligera and Urotricha sp., could be observed in the whole water column. The ciliate abundances of all samples were positively correlated with the chl- $a$ concentrations $\left(\mathrm{r}_{\mathrm{s}}=0.51, \mathrm{p}<0.01\right)$, which suggests algivory of all ciliate groups. The negative correlation with the mean cell length of bacteria (Tab. 4) indicates that filamentous bacteria are not available as prey.

\section{CONCLUSIONS}

The microbial assemblages of the oligotrophic high mountain Lake Gossenköllesee are confronted with extremely low nutrient-concentrations: DOC $\sim 0.4 \mathrm{mg}$ $\mathrm{l}^{-1}$, TDP $\sim 1 \mathrm{~g} \mathrm{l}^{-1}$, and DN $\sim 0.3 \mathrm{mg} \mathrm{l}^{-1}$. Therefore, bacterial abundances are low $\left(3.73 \times 10^{5}\right.$ cells $\left.\mathrm{ml}^{-1}\right)$. The bacterial biomass amounted to $>50 \%$ of the total heterotrophic microbial biomass. Filamentous morphotypes, which can represent $>50 \%$ of the bacterial standing stock, and are thus inedible for small flagellates, seem to be typical for this lake. Although bacteria are below the reported threshold density for bacterivorous protists, the high abundance of flagellates suggests that a considerable proportion may be mixotrophic. The ciliate diversity seemed to be very poor - three abundant species which preferentially feed on algae (three species as single observations) - but can occur at high abundances (B. planctonicum $>16,000$ ind $1^{-1}$ ).

\section{ACKNOWLEDGMENTS}

The authors are grateful to R. Sommaruga, and T. Posch for editorial comments. Thanks also to J. Franzoi and W. Müller for elaboration and H. Thies for providing chemical data. This work was supported by the EU Mountain Lake Research Program (MOLAR) ENV4-CT95-0007.

\section{REFERENCES}

Alfreider, A., J. Pernthaler, R. Amann Sattler B., F.O. Glöckner, A. Wille \& Psenner R. 1996. Community Analysis of the Bacterial Assemblages in the Winter Cover and Pelagic Layers of a High Mountain Lake by In Situ Hybridisation. Appl. Env. Microbiol., 62(12): 2138-2144.

Andreatta, S. 1998. Respiratory Activity of Bacterial Cells in a High Mountain Lake (Gossenköllesee, Tirol) during Icebreak: Quantification of Tetrazolium-Reduction by Image Analysis. Msc at University of Innsbruck., $50 \mathrm{pp}$.

Borsheim, K.Y. \& G. Bratbak. 1987. Cell volume to cell carbon conversion factors for a bacterivorous Monas sp. enriched from sea water. Mar. ecol. Progr. Ser., 36: 171 pp.

del Giorgio, P.A., J.M. Gasol, D. Vaqué, P. Mura, S. Agustí \& C.M. Duarte. 1996. Bacterioplankton community structure: Protists control net production and the proportion of active bacteria in a coastal marine community. Limnol. Oceanogr., 41:1169-1179.
Eppacher, T. 1966. Umweltfaktoren und Lebewelt im Pelagial des Gossenköllesees. PhD dissertation, University of Innsbruck, Austria.

Felip, M. 1997. Ecologia del Microplàncton d'un Estany profund d'alta Muntanya (Redo, Pirineus). PhD-Thesis Univ. Barcelona: $260 \mathrm{pp}$.

Felip, M., B. Sattler, R. Psenner \& J. Catalan. 1995. Highly Active Microbial Communities in the Ice and Snow Cover of High Mountain Lakes. Appl. Environ. Microbiol., 61: 2394-2401.

Fott, J., E. Stuchlík, Z. Stuchlíková, V. Straškrabová, J. Kopácek \& K. Šimek. 1992. Acidification of lakes in Tatra Mountains (Czechoslovakia) and its ecological significance. In: Mosello R., Wathne B. \& Giussani G. (Eds), Limnology on groups of remote mountain lakes: ongoing and planned activities. Documenta Ist. ital. Idrobiol., 32: 69-81.

Gasol, J.M., P.A. del Giorgio, R. Massana \& C.M. Duarte. 1995. Active versus inactive bacteria: size-dependence in a coastal marine plankton community. Mar. Ecol. Prog. Ser., 128: 91-97.

Gonzales, J.M., E.B. Sherr \& B.F. Sherr. 1990. Size-selective grazing on bacteria by natural assemblages of estuarine flagellates and ciliates. Appl. Environ. Microbiol., 56: 583-589.

Havskum, H. \& B. Riemann. 1996. Ecological importance of bacterivorous, pigmented flagellates (mixotrophs) in the Bay of Aarhus, Denmark. Mar. Ecol. Prog. Ser., 137: 251-263.

Kenter, U., U. Zimmermann \& H. Müller. 1996. Grazing rates of the freshwater ciliate Balanion planctonicum determined by flow cytometry. J. Plankton Res., 18: 10471053.

Koinig, K.A., R. Schmidt, S. Sommaruga-Wögrath, R. Tessadri \& R. Psenner. 1998. Climate change as the primary cause for $\mathrm{pH}$ shifts in a High Mountain Lake. Water, Air, and Soil Pollution, 104: 167-180.

Loferer-Krößbacher, M., J. Klima \& R. Psenner. 1998. Determination of Bacterial Cell Dry Mass by Transmission Electron Microscopy and Densitometric Image Analysis. Appl. Env. Microbiol., 64: 688-694.

Müller, H. \& W. Geller. 1993. Maximum growth rates of aquatic ciliated protozoa: the dependence on body size and temperature reconsidered. Arch. Hydrobiol., 126: 315-327.

Norland, S. 1993. The relationship between biomass and volume of bacteria. In: Kemp, B. Sherr, E. Sherr \& J. Cole (Eds), Handbook of Methods in Aquatic Microbial Ecology. Lewis Publ. Boca Raton: 303-308.

Patrick, S., R.W. Battarbee, B. Wathne \& R. Psenner. 1998. Measuring and modelling the dynamic response of remote mountain lake ecosystems to environmental change: an introduction to the MOLAR project. In: Kovar, Tappeiner, Peters, Craig (Eds), Hydrology, water resources and ecology in headwaters. Proceedings of the HeadWater '98 Conference, Merano: Int. Assoc. Hydrol. Sciencies. Publ. 248, IAHS Press, Wallingford.

Pechlaner, R. 1967. Die Finstertaler Seen (Kühtai, Österreich). II. Das Phytoplankton. Arch. Hydrobiol., 63: 145193.

Pernthaler, J., A. Alfreider, T. Posch, S. Andreatta \& R. Psenner. 1997. In Situ Classification and Image Cytometry of Pelagic Bacteria from a High Mountain Lake (Gossenköllesee, Austria). Appl. Env. Microbiol., 63: 4778-4783.

Pernthaler, J., F.O. Glöckner, S. Unterholzner, A. Alfreider, R. Psenner \& R. Amann. 1998. Seasonal Community and Population Dynamics of Pelagic Bacteria and Archaea in a High Mountain Lake. Appl. Env. Microbiol., 64: 42994306. 
Porter, K.G. \& Y.S. Feig. 1980. The use of DAPI for identifying and counting aquatic microflora. Limnol. Oceanogr., 25: 943 - 948.

Posch, T., J. Pernthaler, A. Alfreider \& R. Psenner. 1997. Cell-Specific Respiratory Activity of Aquatic Bacteria Studied with the Tetrazolium Reduction Method, CytoClear Slides and Image Analysis. Appl. Env. Microbiol., 63: 867-873.

Putt, M. \& D.K. Stoecker. 1989. An experimentally determined carbon:volume ratio for marine "oligotrichous" ciliates from estuarine and coastal waters. Limnol. Oceanogr., 34: 1097-1103.

Riemann, B. \& K. Christoffersen. 1993. Microbial trophodynamics in temperate lakes. Marine Microbial Food Webs, 7: 69-100.

Riemann, B. \& M. Søndergaard (Eds). 1986. Carbon $d y-$ namics in eutrophic and temperate lakes. Elsevier Science Publishers B.V.: 127 pp.

Riemann, B., H. Havskum, F. Thingstad \& C. Bernard. 1995. The Role of Mixotrophy in Pelagic Environments. In: I. Joint (Ed.), Molecular Ecology of Aquatic Microbes. Springer Verlag: 87-114.

Sanders, R.W. 1991. Trophic strategies among heterotrophic flagellates. In: Patterson D.J. \& Larsen J. (Eds), The Biology of Free-living Heterotrophic Flagellates. Systematics Association, Spec. Vol. 45: 21-38.

Sattler, B. 1998. Bakterioplankton und Heterotrophe Nanoflagellaten. In: Sommaruga-Wögrath, S. (Eds), Versauerung von Hochgebirgsseen. Bundesministerium für Land- und Forstwirtschaft: 83-101.

Sherr, B.F., E.B. Sherr \& J. McDaniel. 1992. Effect of protistan grazing on the frequency of dividing cells in bacterioplankton assemblages. Appl. Environ. Microbiol., 58: 2381-2385.

Sommaruga, R. \& R. Psenner. 1995. Trophic interactions within the microbial food web in Piburger See (Austria). Arch. Hydrobiol., 132: 257-278.

Sommaruga, R. \& R. Psenner. 1997. Ultraviolet Radiation in a High Mountain Lake of the Austrian Alps: Air and Underwater Measurements. Photochemistry and Photobiology, 65: 957-963.
Sommaruga, R., A. Oberleiter \& R. Psenner. 1996. Effect of UV Radiation on the Bacterivory of a Heterotrophic Nanoflagellate. Appl. Env. Microbiol., 62: 4395-4400.

Steinböck, O. 1938. Arbeiten über die Limnologie der Hochgebirgsgewässer. Int. Rev. Hydrobiol., 37(4/5).

Steinböck, O. 1955. Über die Verhältnisse in der Tiefe der Hochgebirgsseen. Mem. Ist. Ital. Idrobiol. Suppl. 8: 311343.

Stockner, J.G. \& K.G. Porter. 1987. Microbial Foodwebs in Freshwater Planktonic Ecosystems. In: Stephen C. (Ed.), Complex interactions in Lake Communities. Springer Verlag New York.

Straškrabová, V. \& K. Šimek. 1993. Microbial loop in lakes and reservoirs related to trophy and metazooplankton development. Verh. int. Ver. Limnol., 25: 1183-1186.

Straškrabová, V., C. Callieri, P. Carrillo, L. Cruz-Pizarro, J. Fott, P. Hartman, M. Macek, J.M. Medina-Sánchez, J. Nedoma \& K. Šimek. 1999. Investigations on pelagic food webs in mountain lakes - aims and methods. In: Straškrabová, V., C. Callieri \& J Fott (Eds), Pelagic food web in mountain lakes. MOuntain LAkes Research Program. J. Limnol., 58(2): 77-87.

Thies, H., U. Nickus, C. Arnold, R. Schnegg, A. Wille \& R. Psenner. (1999). Biogeochemistry of a High Mountain Lake in the Austrian Alps. Posterpresentation at SIL (Dublin, Aug. 1998). Verh. int. Ver. Limnol., (in press).

Tilzer, M. 1973. Dynamik der planktischen Urproduktion unter den Extrembedingungen des Hochgebirgssees. In: Ellenberg (Ed.), Ökosystemforschung, B, Springer Verlag, Berlin: 51-59.

Wathne, B. (Ed.). 1996. MOLAR - Project manual draft of September 1996. NIVA Rep. No. 0-96061,182; NIVA, Oslo, Norway: $182 \mathrm{pp}$.

Weisse, T. \& J.G. Stockner. 1993. Eutrophication: the role of microbial food webs. In: de Bernardi, R., Pagnotta R. \& Pugnetti A. (Eds), Strategies for lake ecosystems beyond 2000. Mem. Ist. ital. Idrobiol., 52: 133-150.

Zschokke, F. 1900. Die Tierwelt der Hochgebirgsseen. Neue Denkschr. Schweiz. Ges. f. d. ges. Naturwissenschaften. 